\title{
The Effect of Perceived Risk on Repurchase Intention and Word - of - Mouth in the Mobile Telecommunication Market: A Case Study from Vietnam
}

\author{
Nguyen Xuan Tho ${ }^{1}$, Min-Tsai Lai ${ }^{2}$, Huey Yan $^{2}$ \\ ${ }^{1}$ Ph.D. Program in Business and Management, Southern Taiwan University of Science and Technology, Taiwan \\ ${ }^{2}$ College of Business, Southern Taiwan University of Science and Technology, Taiwan \\ Correspondence: Nguyen Xuan Tho, Ph.D. Program in Business and Management, Southern Taiwan University \\ of Science and Technology, No. 1, Nan-Tai Street, Yongkang Dist., Tainan City 710, Taiwan. \\ E-mail: Khoanhkhac2008@gmail.com
}

\author{
Received: October 10, 2016 \\ Accepted: January 11, 2017 \\ Online Published: January 22, 2017 \\ doi:10.5539/ibr.v10n3p8 \\ URL: http://dx.doi.org/10.5539/ibr.v10n3p8
}

\begin{abstract}
This study aims at examining the effect of perceived risk on repurchase intention and positive word-of- mouth (WOM). An online survey method was used to collect data, and 268 questionnaires were properly completed and submitted by subscribers in the Vietnam's mobile telecommunication market. First-order and second-order CFA were established to analyze and confirm dimensions of perceived risk and its construct by using AMOS software. Then, the structure equation model (SEM) was used to test hypotheses. The results show that perceived risk has a significantly negative impact on repurchase intention. The findings also indicate that there is a negative relationship between perceived risk and word - of - mouth. Based on scientific proof as well as practical evidence, it suggests that the mobile service providers in Vietnam need to prevent any cause that may lead to an increase in terms of consumer's risky perception in order to retain existing subscribers and attract more potential customers.
\end{abstract}

Keyword: perceived risk, WOM, first-order and second-order CFA, SEM, mobile telecommunication market, Vietnam

\section{Introduction}

As of August 2016, the mobile telecommunication market in Vietnam has more than 128.3 million subscribers using service of five providers - Viettel, Vinaphone, MobiFone, Vietnamobile, and Gtel (Gmobile). However, the market is dominated by Viettel, Vinaphone, MobiFone. Accordingly, they are holding a majority of market share in the mobile telecommunication industry of Vietnam. The Viettel holds the highest market share of $49.5 \%$, next the MobiFone occupies approximately $27 \%$, followed by the Vinaphone with nearly $16 \%$ (Ministry of Information \& Communications [MIC], 2016). Presently, although the mobile telecommunication market in Vietnam is generally saturated in the number of subscribers, the competition is still very fierce in a market structure with constantly fluctuating number of subscribers among service providers. This is a challenge to attract more new customers, so the service providers focus more on retaining existing customer through loyalty programs. Furthermore, there is a fact that the cost of attracting new users is much higher than the cost of retaining existing subscribers, thus "keeping customer loyalty is a crucial issue for service firms" (Liu, Guo \& Lee, 2011).

A number of previous studies have confirmed some factors which have an impact on customer loyalty in the field of mobile telecommunication service. For example, service quality (Eshghi, Roy, \& Ganguli, 2008; Lee \& Murphy, 2008; Ishaq, 2012; M. Hassan, S. Hassan, Nawaz, \& Aksel , 2013), corporate image (Kim, Park, \& Jeong, 2004; Jallow, 2013; Bayraktar, Tatoglu, Turkyilmaz, \& Zaim, 2012; Aydin \& Ozer, 2005; Hafeez \& Hasnu, 2010; Vranakis, Chatzoglou, \& Mpaloukas, 2012), switching barrier (Kim et al., 2004; Liu, Guo \& Lee, 2011; Almossawi, 2012; Aydin \& Ozer, 2005), perceived value (Bayraktar et al., 2012; Ishaqa, 2012), customer trust (Liu, Guo \& Lee, 2011; Ahmad, Husain \& Rajput, 2015), etc. However, within this service market, there seems to be a lack of research about examining the relationship between customer perceived risk and customer loyalty (particularly focus on repurchase intention and positive WOM). It might be argued that the effect of 
perceived risk on repurchase intention and word-of-mouth is well investigated in literature. However, due to lack of research in this industry as was mentioned above and consumer's perceived risk may vary in different sectors or markets, this study will ignore some main components of service quality to focus on examining the effect of perceived risk on repurchase intention (consumer's intention of using mobile network over the long term) as well as on positive word-of-mouth in the Vietnam's mobile telecommunication market. It is expected that the study will bring out not only the scientific proof but also the empirical evidence in order to persuade the Vietnam's mobile network operators that they should stand on consumer's point of views to understand subscriber's perceived risk. As a result, the operators may adjust their policy and strategy to meet customer's need in order to retain existing subscribers in this intensely competitive environment.

The paper begins with literature review: some key terms will be explained based on previous studies. Definition of perceived risk dimensions examined in this study will be also clarified. In the next section, the questionnaire's structure and methodologies to analyze data will be presented. Then the results of the study will be shown in detail, followed by the discussion section. Finally, several limitations and future research direction will be mentioned.

\section{Literature Review}

\subsection{Two Main Dimensions of Customer Loyalty}

Customer loyalty has been considered as the frequency or quantity of purchase from a specific product/brand. The current literature regarding customer loyalty only focuses on customers and does not take the psychological meaning of loyalty into account (Ansari \& Riasi, 2016). Being aware of different dimensions of customer loyalty can help to resolve this problem.

The concept of customer loyalty can be approached from both two perspectives, attitudinal and behavioral, or one of them. From behavioral perspective, loyalty "can be converted into actual purchase behaviors" (Cheng, 2011), and loyal customer tend to repurchase and keep the relationship with service providers (Jones and Taylor, 2007). On the other hand, attitudinal loyalty can be recognized in terms of attitudes or commitment towards a particular service provider (Söderlund, 2006), or preference of a service or product over alternatives (Jones and Taylor, 2007); and, through word-of-mouth, customers are willing to "create a positive image of a business to others" (Cheng, 2011). Some other previous researchers emphasized on repurchase intention and word-of-mouth to make mention of behavioral intention (Fornell, 1992; Oliver, 1999; Tho \& Tuu, 2012). Accordingly, loyal customers will not only have intention of purchasing again and again, but also would be willing to recommend to others about the products or services that they have experienced. In this paper, the concept customer loyalty is considered on two main dimensions, including repurchase intention and positive word-of mouth.

\subsubsection{Repurchase Intention}

Repurchase intention or customer retention is acknowledged as the likelihood of using a service provider again in the future (Fornell, 1992), and it is "an individual's judgment about buying again a designated service from the same company, taking into account his or her current situation and likely circumstances" (Hellier, Geursen, Carr, \& Rickcard, 2003). Hume, Mort, and Winzar (2007) defined as the consumer's decision to commit with the firms or providers in term of future activities. It is regarded as an indicator to measure reaction of consumers to certain experiences on their consumption, and it can be obtained by opinion polls from current customers. Repurchase intention is the most vital goal for company success (Jones \& Sasser, 1995), and it has been considered as a remarkably important concept in marketing until now. According to Lee, J. Lee, and Feick (2001), loyal customers tend to purchase same product again and again or to buy different products or services of the same provider. As the cost of maintaining existing loyal customers is lesser than that of attracting new customers, the repurchase intention of a customer is very important for any business organization (Samad, 2014). As a result, it seems that almost companies are focusing more on retaining their existing subscribers rather than looking for more new customers.

\subsubsection{Word - of - Mouth}

Word-of-mouth is defined as "the sharing of information from one person to another" (Khalid, Ahmed, \& Ahmad, 2013), or "the passing of information from person to person by oral communication" (Maisam \& Mahsa, 2016). It is a form of advertising in which customers are likely to give any recommendation about products or service in their living environments, and as such creating "a chain of communication that could reach a whole community" (Mason, 2008). Mutual conversations, unilateral advices, or suggestions can be also considered as forms of expressing of word of mouth (Maisam \& Mahsa, 2016), and it has been recognized as "an effective medium for dissemination of information" (Khan, Ahmed, \& Ahmad, 2015). According to Maisam and Mahsa (2016), word 
of mouth is "one of the ways that has the most effect on the people and persuades people to buy a product or service more than other commercials because people usually trust to what they hear directly from others". The people who spread information do not have any intention of doing business, and the providers are not directly involved. Also, they may transmit negative or positive word-of-mouth. In this paper, positive WOM is mentioned as one dimension of loyalty.

\subsection{Perceived Risk}

Perceived risk can be explained as "consumer's doubt about the result of their decisions" (Arslan, Gecsti, \& Zengin, 2013). According to Cox and Rich (1964), the concept of perceived risk includes at least two aspects, adverse consequences and uncertainties. Risk can be encountered during consumer's purchasing process, or once they face to any potential uncertainty and undesirable consequence (Taylor, 1974; Zhang, W. Tan, Xu, \& G. Tan, 2012). Therefore, if the purchase result was not favorable, customers would be lost their budget, wasted their time, damaged their social position, etc (Cabañero \& Carmen, 2007).

According to Jacoby and Kaplan (1972), several types of risk that consumers perceive can be considered: functional risk, physical risk, financial risk, social risk, and psychological risk. Zhang et al. (2012) proposed and verified more dimensions of perceived risk, which include social risk, economics risk, privacy risk, time risk, quality risk, health risk, delivery risk, after-sale risk. In addition, Alamsyah and Angliawati (2015) also brought out several dimensions to measure the concept of perceived risk, followings financial risk (price, cost, funding), functional risk (needs, functions, beliefs), and psychosocial risk (stress, dislike, refuse). Thus, the perceived risk can be considered in term of economic/functional aspects, psychological/social elements, or some combination of both forms (Taylor, 1974). Accordingly, dimensions of perceived risk which are mentioned in this study will be presented in the table below:

Table 1. Definition of perceived risk dimensions

\begin{tabular}{lll}
\hline Variable & \multicolumn{1}{c}{ Definition } & \multicolumn{1}{c}{ Source } \\
\hline Financial risk & The possibility of losing money when buying/using a poor & Jacoby \& Kaplan (1972), \\
& product or service (Jacoby \& Kaplan, 1972; Beneke, & Beneke et al., (2012), Tho \& \\
& Greene, Lok, \& Mallet, 2012; Tho \& Tuu, 2012; Tuu, Tuu (2012), Zhang et al. \\
& Olsen, \& Linh, 2014), or probably monetary loss due to (2012); Tuu et al. (2014), and \\
& fraud (Zhang et al., 2012), or potentially financial loss as a this study
\end{tabular}
consequence of the service provider's mistake.

Psychosocial risk (social Customers worry about losing their status in one's social and psychological risk) group as a consequence of purchasing a particular product or service (Jacoby \& Kaplan, 1972; Beneke et al., 2012; Zhang et al., 2012; Tho \& Tuu, 2012). Besides that, consumers feel disappointed with a poor product or service because it has failed to fulfill their hopes (Beneke et al., 2012), or they may be underestimated by others (Tho \& Tuu, 2012),

Message risk

The risk associated to failure by message service to fulfill subscriber's need. In detail, consumers worry about receiving any message related to unexpected ads, game

Jacoby \& Kaplan (1972); Beneke et al., (2012); Zhang et al., 2012; Tho \& Tuu (2012) and this study

This study invitations, or phishing attacks.

\subsection{Perceived Risk and Repurchase Intention}

According to Taylor (1974), "once perceived risk has been identified in a purchase situation, there seems to be some reasonable evidence that subsequent consumer behavior can be determined in accordance with such risk". Risk can be occurred during purchasing process or consumption, and it has a negative impact on consumer's attitude (Zhang et al., 2012). The degree of consumer's risky perception is one of the important factors, which influences on their buying decision (Schiffman \& Kanuk, 2010). The more risk customer perceive, the less likely it is that they will make a purchase (Zhang et al., 2012); because the fact that "consumers are more often motivated to avoid mistakes than to maximize utility in purchasing" (Mitchell, 1999). Therefore, the first hypothesis would be:

\section{Hypothesis 1: Perceived risk has a negative impact on repurchase intention}

\subsection{Perceived Risk and Positive WOM}

Lin and Fang (2006) presumed that people will not spread positive word-of-mouth when a product is considered in inherently risky circumstances. According to Lampert and Rosenberg (1975), when consumers seem to perceive low risk from a product or service, they will engage more word-of-mouth activity. In addition, in high risky situation, consumers are more likely to think about the potentially negative consequences when they make 
a decision (Beisswanger, Stone, Hupp, \& Allgaier, 2003). More recently, Tho and Tuu (2012) also asserted that perceived risk has negative association with positive word-of-mouth. Thus, the second hypothesis was proposed:

Hypothesis 2: Perceived risk has a negative effect on positive WOM

\section{Conceptual Model}

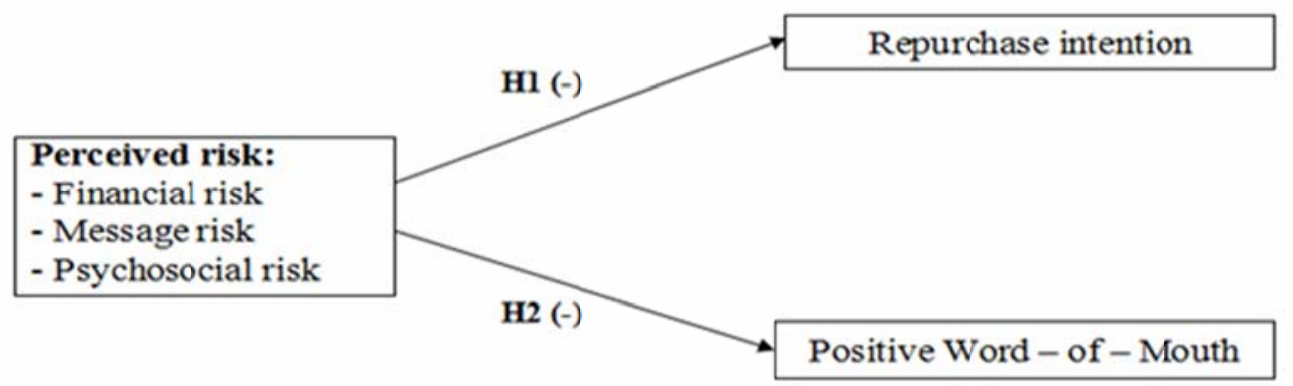

Figure 1. Theoretical Framework

\section{Methodology}

\subsection{Questionnaire and Data Collection}

A self-administered questionnaire was selected for survey. It consists of five components: (1) measure "financial risk" (FR) with three questions adapted from Tho and Tuu (2012), and Tuu et al. (2014); (2) four items were created in order to observe "message risk" (MR); (3) evaluate "psychosocial risk" (PR) with three questions fitted from Tho and Tuu (2012); (4) also, three questions were used to measure "repurchase intention" (RI) (Chaudhuri \& Holbook, 2001; Eshghi, Roy, \& Ganguli, 2008; Tho \& Tuu, 2012; Hassan et al., 2013; Nasir \& Mushtaq, 2014); and (5) two items for evaluating "WOM" (W) (Chaudhuri \& Holbook, 2001; Eshghi et al., 2008; Tho \& Tuu, 2012; Nasir \& Mushtaq, 2014).

The questionnaire was first pretested with a group of 30 lecturers of the NgheAn University of Economics (Vinh city, Vietnam). These lecturers were also asked to revise the content and structure of the questionnaire. In line with their comments, we combined psychological risk and social risk into one dimension, namely psychosocial risk in the final questionnaire. A five point Likert scale questionnaire was posted in some facebook groups and e-mailed to collect data. After over two months, a total of 296 questionnaires were collected. However, only 268 properly competed questionnaires were used in this paper.

\subsection{The Data Analysis Process}

Firstly, descriptive statistics were used to highlight the respondent profiles. Then, first-order and second-order CFA were established to analyze dimensions of perceived risk and its construct. Finally, the Structure Equation Model (SEM) was used to test proposed hypotheses.

Table 2. Profile of respondents $(\mathrm{N}=268)$

\begin{tabular}{|c|c|c|c|}
\hline & Category & Number of samples & Percentage \\
\hline \multirow[t]{2}{*}{ Gender } & Male & 102 & 38.1 \\
\hline & Female & 166 & 61.9 \\
\hline \multirow[t]{3}{*}{ Age } & $\leq 25$ & 108 & 40.3 \\
\hline & $25-40$ & 102 & 38.1 \\
\hline & $\geq 40$ & 58 & 21.6 \\
\hline \multirow{4}{*}{$\begin{array}{l}\text { Mobile network } \\
\text { operator }\end{array}$} & Viettel & 106 & 39.6 \\
\hline & Vinaphone & 86 & 32.1 \\
\hline & MobiFone & 70 & 26.1 \\
\hline & $\begin{array}{l}\text { Others } \\
\text { Gmobile-Gtel) }\end{array}$ & 6 & 2.2 \\
\hline \multirow[t]{2}{*}{ Payment choice } & Prepaid & 209 & 78.0 \\
\hline & Postpaid & 59 & 22.0 \\
\hline \multirow[t]{5}{*}{ Occupation } & Public Servant & 55 & 20.5 \\
\hline & Private sector employee & 69 & 25.7 \\
\hline & Student & 99 & 36.9 \\
\hline & Freelancer & 38 & 14.2 \\
\hline & Others & 7 & 2.6 \\
\hline
\end{tabular}




\section{Analysis and Results}

\subsection{Respondent Profiles}

As shown in the demographic profile (table 2), the survey is dominated by females $(61.9 \%)$. The table also indicates that the majority of respondents $(39.6 \%)$ are using service provided by Viettel. The runner-up is Vinaphone (32.1\%), followed by MobiFone (26.1\%). Only 2.2\% of the sample use Vietnammobile and Gmobile (Gtel). Most respondents (78\%) consume prepaid cards while only $22 \%$ choose monthly bills.

\subsection{First and Second-order CFA for Perceived Risk}

First-order CFA was applied to test how well measured variables represent in the dimensions (financial risk, message risk, psychosocial risk). According to Malhotra (2004), the value of coefficient alpha falls below 0.6 is considered weak in reliability, while it falls into the range of $0.6-0.8$ is recognized moderate strong, and the range of 0.8-1.0 is acknowledged very strong in reliability. In addition, the rule from Clark and Watson (1995) suggested that reliability-related critical value must be at least 0.60 and the values below that value are unacceptable. In order to be better of model and reliability of observable variables, based on Cronbach's alpha and item loading, therefore some items were removed from initial model (MR1, PR3). The results of first-order CFA show in table 3.

Table 3. First-order of perceived risk measurement model

\begin{tabular}{|c|c|c|c|}
\hline \multicolumn{2}{|c|}{ Scale/items } & Item loading & Cronbach's Alpha $(\alpha)$ \\
\hline \multicolumn{3}{|c|}{ Financial risk $(\mathrm{CR}=0.73 ; \mathrm{AVE}=0.48)$} & 0.74 \\
\hline \multirow{3}{*}{\multicolumn{2}{|c|}{$\begin{array}{l}\text { FR1: It is difficult to control my account balance. } \\
\text { FR2: Sometimes my account balance is deducted without any reason. } \\
\text { mistake }\end{array}$}} & 0.64 & 0.66 \\
\hline & & 0.77 & 0.65 \\
\hline & & 0.66 & 0.66 \\
\hline \multicolumn{3}{|c|}{ Message risk $(\mathrm{CR}=0.78 ; \mathrm{AVE}=0.55)$} & 0.77 \\
\hline \multicolumn{3}{|c|}{ MR1: I often get many unwanted advertising messages on my phone } & 0.76 \\
\hline \multicolumn{2}{|c|}{ MR2: I often get many game invitations on my phone } & 0.76 & 0.67 \\
\hline \multicolumn{2}{|c|}{ MR3: I often get many phishing attacks on my phone } & 0.83 & 0.61 \\
\hline \multicolumn{3}{|c|}{ Psychosocial risk $(\mathrm{CR}=0.78 ; \mathrm{AVE}=0.64)$} & 0.77 \\
\hline \multirow{2}{*}{\multicolumn{2}{|c|}{$\begin{array}{l}\text { PR1: My family members do not want me to use this mobile phone network } \\
\text { PR2: I am underestimated when using this mobile network }\end{array}$}} & 0.72 & 0.61 \\
\hline & & 0.87 & 0.66 \\
\hline $\begin{array}{l}\text { Square of correlation } \\
\quad\left(\mathrm{CORR}^{\wedge} 2\right) \text { : }\end{array}$ & $\begin{array}{l}\text { Financial risk }<->\text { Message risk } \\
\text { Message risk }<->\text { Psychosocial } \mathrm{r} \\
\text { Financial risk }<->\text { Psychosocial }\end{array}$ & .26 & \\
\hline Model fit indices: & \multicolumn{2}{|c|}{$\begin{array}{l}\text { Chi-square }=35.915 ; \mathrm{Df}=17 ; \text { Chi-square } / \mathrm{df}=2.07 ; \\
\text { p-value }=0.006 \mathrm{GFI}=0.967 ; \text { AGFI }=0.931 ; \\
\text { CFI }=0.972 ; \text { IFI }=0.972 ; \text { RMSEA }=0.063\end{array}$} & \\
\hline
\end{tabular}

The table 3 show that item loadings ranged from 0.64 to 0.77 for financial risk, 0.62 to 0.83 for message risk, and 0.72 to 0.87 for psychosocial risk. All of composite or construct reliability (CR) of the measurement constructs are above 0.7 (Straub, 1989). Also, all of the constructs (except financial risk) have the average variance extracted (AVE) values greater than 0.5 (Fornell \& Larcker 1981; Hair, Anderson, Tatham, \& Black 1998). Cronbach's alpha coefficients for the measures ranged from 0.61 and 0.87 . There are evidences that the model provides good fit $($ Chi-square $=35.915$; Degrees of freedom $=17 ; \chi 2 / \mathrm{df}=2.07$; GFI $=0.967 ;$ AGFI $=$ 0.931; IFI $=0.972 ; \mathrm{CFI}=0.972 ; \mathrm{RMSEA}=0.063$ ).

According to Bagozzi, Li, and Philips (1991), if all factor loadings for traits are statistically significant, convergent validity will be satisfied. As both the fit indices and item loadings of each factor are exceeding the critical value (0.6), which was recommended by Nunnally (1967), it can be said that convergent validity is ensured for the dimensions of perceived risk.

Second-order CFA was employed to specify to what extent the sub-dimensions of perceived risk explain the concept. Results indicate that Financial risk is the most reliable indicator $(0.79)$ followed by message risk $(0.66)$, and psychosocial risk (0.65) (see in table 4).

Table 4. Second-order CFA of perceived risk measurement model

\begin{tabular}{lc}
\hline \multicolumn{1}{c}{ Structural parameters } & Factor loading \\
\hline Perceived risk $\rightarrow$ Financial risk & 0.79 \\
Perceived risk $\rightarrow$ Message risk & 0.66 \\
Perceived risk $\rightarrow$ Psychosocial risk & 0.65 \\
\hline \multicolumn{2}{c}{ Model fit indices: Chi-square $=35.915 ; \mathrm{Df}=17 ;$ Chi-square $/ \mathrm{df}=2.07 ; \mathrm{p}$-value $=0.006$} \\
$\qquad$ GFI $=0.967 ;$ AGFI $=0.931 ;$ CFI $=0.972 ;$ IFI $=0.972 ;$ RMSEA $=0.063$ \\
\hline
\end{tabular}




\subsection{Discriminant Validity Test}

In order to evaluate the degree to which measures of different concepts are distinct, discriminant validity test is used. The AVE method (average variance extracted method) is used to test discriminant validity. According to Fornell and Larcker (1981), If the average variances extracted (AVE) by the correlated latent variables is greater than the square of the correlation $\left(\mathrm{CORR}^{\wedge} 2\right)$ between the latent variables then discriminant validity satisfies. The results (see table 5) indicate that two pair of constructs (Perceived risk \& Repurchase intention and Repurchase intention \& WOM) satisfy with the discriminant validity. However, the CORR ^2 (WOM spread and Perceived risk: 0.53) is greater than the AVE of Perceived risk (0.51) and smaller than the AVE of WOM (0.81). Thus, AVE method fails to check the discriminant validity between two constructs of "Perceived risk" and "WOM". Therefore, it is necessary to find other alternative method.

Table 5. Confirmation Factor Analysis for Convergent and Discriminant Validity

\begin{tabular}{|c|c|c|c|c|c|}
\hline $\mathrm{AVE} / \mathrm{CORR}^{\wedge} 2$ & $\alpha$ & $\begin{array}{c}\text { Construct } \\
\text { reliability } \\
(\mathrm{CR})\end{array}$ & Perceived risk & $\begin{array}{l}\text { Repurchase } \\
\text { intention }\end{array}$ & WOM \\
\hline 1. Perceived risk & 0.795 & 0.74 & 0.51 & & \\
\hline 2. Repurchase intention & 0.846 & 0.85 & 0.25 & 0.74 & \\
\hline 3. WOM & 0.879 & 0.66 & 0.53 & 0.38 & 0.81 \\
\hline \multicolumn{6}{|c|}{$\begin{array}{l}\text { Model fit indices: } \text { Chi-square }=90.553 ; \mathrm{Df}=48 ; \text { Chi-square } / \mathrm{df}=1.887 ; \mathrm{p} \text {-value }=0.000 \\
\text { GFI }=0.947 ; \mathrm{AGFI}=0.914 ; \mathrm{CFI}=0.968 ; \mathrm{IFI}=0.969 ; \mathrm{RMSEA}=0.58\end{array}$} \\
\hline \multicolumn{6}{|c|}{$\begin{array}{l}\text { One of the alternative methods to check discriminant validity was recommended by Bagozzi et al. (1991), using } \\
\text { Chi-square different test. Accordingly, chi-square differences between Model 1, where correlation fixed at } 1 \text {, and } \\
\text { Model 2, where correlations were free. If chi-square of two models is different, it means that the discriminant } \\
\text { validity was satisfied between two constructs. The results of Chi-square difference test of two constructs } \\
\text { (Perceived risk and WOM) are presented in table 6: }\end{array}$} \\
\hline \multicolumn{6}{|c|}{ Table 6 . The result of Chi-square differences test } \\
\hline Model & & Chi-square & & & P-value \\
\hline Model 1 (Correlations fixed at 1) & & 430.292 & & & $* * *$ \\
\hline Model 2 (Correlations free) & & 67.252 & & & $* * *$ \\
\hline Difference of Chi-square & & 363.04 & & & \\
\hline Difference of DF & & & & & \\
\hline
\end{tabular}

Note: $* * *$ significant at $1 \%$ level

The results show that chi-square value of the fixed model (model 1) was higher than the unconstrained one (model 2). The Chi-square difference test result was significant (P-value $<0.01$ ), therefore, two constructs of "Perceived risk" and "WOM" satisfy with the discriminant validity.

\subsection{Hypothesis Test}

The structural equation model was employed to test hypotheses of research. The results are shown in figure 2 below:

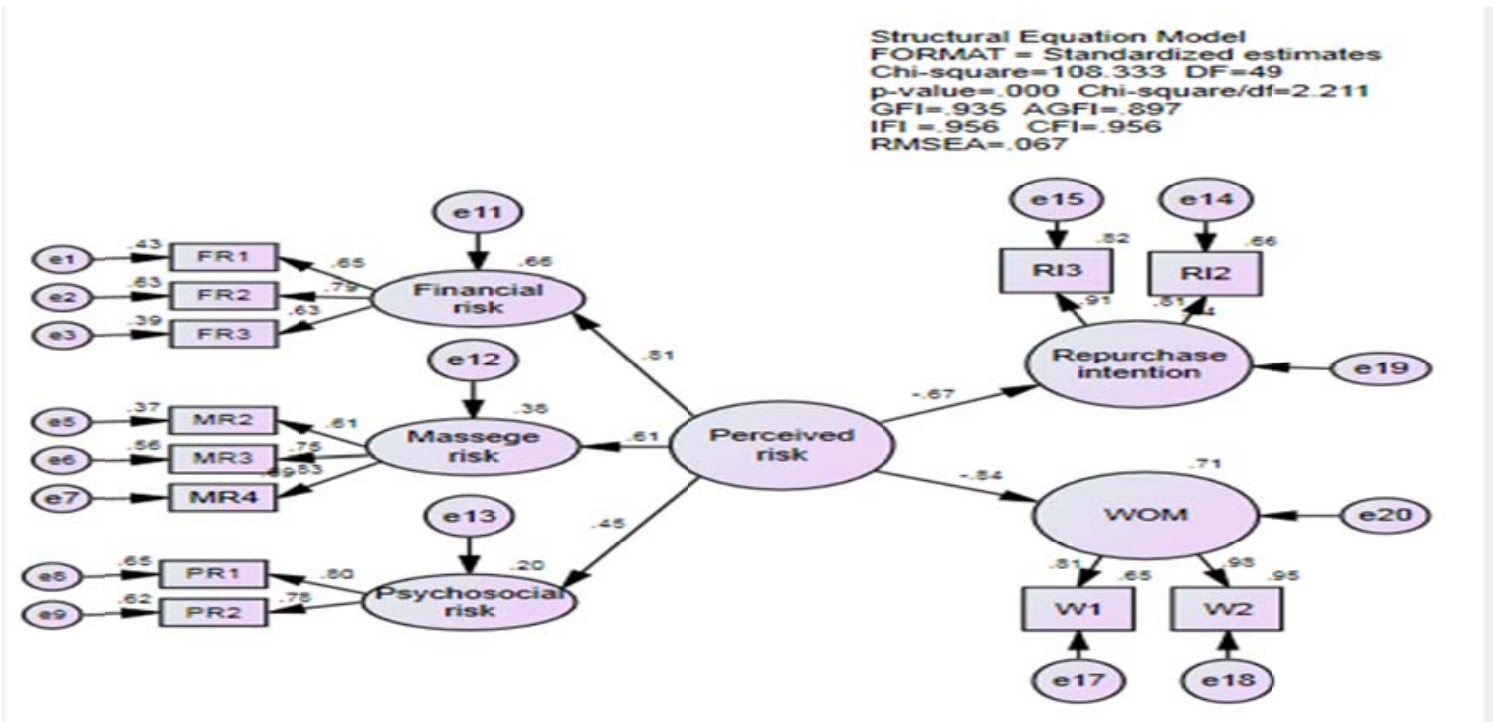

Figure 2. Results of structural modeling analysis 
Table 7. Results of hypothesis test

\begin{tabular}{|c|c|c|c|c|}
\hline Hypothesized path & $\begin{array}{l}\text { Standard } \\
\text { Estimates }\end{array}$ & t- value & Sig. & Result \\
\hline H1: Perceived risk $\rightarrow$ Repurchase intention & -0.67 & -7.128 & $* * *$ & Accepted \\
\hline H2: Perceived risk $\rightarrow$ WOM spread & -0.84 & -8.109 & $* * *$ & Accepted \\
\hline $\begin{array}{l}\text { Model fit indices: } \text { Chi-square }=108.333 ; \mathrm{DF}= \\
\mathrm{P}-\mathrm{value}=0.000 ; \mathrm{GFI}=0.935 ; \mathrm{AGFI}=0.897 \\
\text { Note: } * * * \text { Significant at } 1 \% \text { level }\end{array}$ & $\begin{array}{l}\mathrm{e} d \mathrm{df}=2.211 \\
=0.956\end{array}$ & $A=0.67$ & & \\
\hline
\end{tabular}

The results in table 7 indicate that the hypothesis $\mathrm{H} 1$ and $\mathrm{H} 2$ are accepted. It means that perceived risk has a negative effect on repurchase intention and positive WOM.

\section{Discussion and Conclusion}

According to Yanamandram and White (2006), in order to assess the model, "reliance on the chi-square test as the sole measure of fit in a structural equation model is not recommended due to its sensitivity to sample size", especially for cases in which the sample size exceeds 200 respondents (Hair et al., 1998; Tabachnick \& Fidell, 1996).

Therefore, some alternative stand-alone fit indices which are less sensitive to sample size will be used in order to assess the overall model fit. These indices include the Normed chi-square or chi-square /df, the Comparative Fit Index (CFI), the Incremental Fit Index (IFI), the Goodness-of-Fit (GFI), and the Adjusted goodness-of-fit index (AGFI) (Bagozzi \& Yi, 1988; Byrne, 2010; Hair et al., 1998; Joreskog \& Sorbom, 1993). The rule of thumb: Chi-square divided by degree of freedom (normed chi-square) should be less than 3 (Carmine \& McIver, 1981; Kline, 2005); however, Joreskog and Sorbom (1993) suggested that it should be less than or equal 2 to have an acceptable level of model fit. A value of GFI, IFI, CFI at least 0.90 was required to accept a model (Bagozzi \& Yi, 1988; Bollen, 1989; Joreskog \& Sorbom, 1993; Hair et al., 1998), while a value of at least 0.95 was required to ensure a good level of model fit (Hox, 2002; Hooper, Couhlan, \& Mullen, 2008). The value of AGFI should exceed 0.8 (Joreskog \& Sorbom, 1993).

Another approach for assessing how well a model fits the data, in order to accept it, by using the value of RMSEA (Root Mean Square Error of Approximation) (Joreskog \& Sorbom, 1993; Yanamandram \& White, 2006). Some researchers claimed that RMSEA need to be less than 0.08 (Steiger, 1990; MacCallum, Browne, Sugawara, 1996; McQuitty, 2004), some others recommended that it should be below 0.07 (Bollen, 1989; Steiger, 2007; Hoop, Couhlan, \& Mullen, 2008). However, Hu and Bentler (1999) suggested that RMSEA should be less than 0.06, while Schumaker and Lomax (2004) propounded that there is a good model if RMSEA is less than or equal to 0.05 . Thus, it is safe to say that a value between 0.05 and 0.08 is indicative of acceptable model fit (Yanamandram \& White, 2006). The results of model fit indices (see Figure 2) indicate that the model proposed in this study has an acceptable fit to data.

The results of structural equation modeling analysis indicate that perceived risk in the Vietnam's mobile telecommunication market has a significant and negative effect on repurchase intention. Thus, proposed hypothesis $\mathrm{H} 1$ is accepted. This finding is consistent with previous researches in other industries (Schiffman \& Kanuk, 2010; Tho \& Tuu, 2012; Zhang et al., 2012), which have shown that once customers sense more perceived risk from a product or service, they would not intend to purchase again. In other words, the more risk consumers perceive, the less likely they will make a purchase or have intention of repurchasing products or services.

Contrary to the first time finding from a study conducted by Lin and Fang (2006), this research examined the relationship between perceived risk and word-of-mouth resulted in a different finding. As hypothesis $\mathrm{H} 2$ is supported, it confirms that people will avoid spreading positive word-of-mouth when a product or service is perceived under risky circumstances. It is consistent with Tho and Tuu (2012), when perceived risk towards services increases, customers tend to close their positive WOM, and they will probably spread negative WOM instead.

There are some reasons to explain why perceived risk only consists of three dimensions in this study. First, in the pilot phase, four dimensions were taken into consideration, namely financial risk, message risk, psychological risk and social risk. However, most pilot survey participants suggested that given their high interaction, psychological risk and social risk should be combined in order to better reflect consumer behavior in this industry. Second, this study conducted in Vietnam where the market structure of mobile telecommunication service is not stable yet. In addition, a legal framework for the market has been inefficient until now. Cell phone users, therefore, have often received spam messages such as unexpected advertisements, game invitations and phishing attacks in recent years. Besides that, Vietnamese subscribers have sometimes complained about 
inexplicable or inaccurate deductions from their account balance. It means that subscribers have suffered from several kinds of financial problems, namely financial risk in this paper.

In conclusion, the purpose of this study is to examine the effect of perceived risk of existing customers on their repurchase intention (intention of using cell phone network over the long term) as well as on their intention of spreading positive word-of-mouth in the field of mobile telecommunication market of Vietnam. To do this, a framework was built with two hypotheses which propose the relationships between these constructs. First-order and second-order CFA were established to analyze and confirm dimensions of perceived risk and its construct. After doing this, the structure equation model was employed to test proposed hypotheses. As a result, the findings show that two hypotheses were supported. The findings in this study brought out evidences, both on scientific aspect as well as practical side, to suggest that it would be more profitable for any cellular network service provider in Vietnam when finding out effective policies and strategies to meet customer's need in this intensely competitive environment.

Indeed, Vietnamese's highly saturated mobile telecommunications market is a challenge for its mobile services providers. It is essential for them to fully understand the degree of consumers' perceived risk that impacts on their subscriber's intention of spreading positive word-of-mouth and intention of using mobile network over the long term. The better strategy for the mobile service operators is that they have to not only maintain high service quality but also eliminate any factor which increases consumer's perceived risk level. The more effective policy the cell network providers make to reduce the level of consumer's risky perception, the more profit they can get from their customer.

\section{Limitation and Future Research Direction}

Similar to the other studies, this research has a few limitations. First, given the fact that the survey covered only volunteers, our research team observed that most respondents were young (U40) and female. This issue might affect the representative sample even though the questionnaire was completed directly by consumers. In order to reduce this problem, both online survey and traditional survey should be carried out in next research studies. Second, in order to focus on consumer's perceived risk, this study did not take into account some main components of service quality that may affect more on behavioral intention. Therefore, it could be argued that its practical contributions are limited in general. In addition, some other factors also need to be examined in future researches, such as customer trust, customer familiarity, advertising, etc. All these factors need to be structurally analyzed for their influence on repurchase intention and word-of-mouth. It can be expected that the newly developed model will lead to more complete findings and greater practical signification.

\section{Acknowledgments}

The authors would like to thank for editor, editorial assistant, and anonymous reviewers' valuable comments and constructive suggestions. The authors are responsible for any remaining error in this article.

\section{References}

Ahmad, J., Husain, M., \& Rajput, A. (2015). Customer loyalty framework of telecommunication service market. International Journal of Managing value and Supply chains (IJMVSC), 6(1), 69-78. Retrieved from https://doi.org/10.5121/ijmvsc.2015.6106

Alamsyah, D. P., \& Angliawati, R. Y. (2015). Buying behavior of organic vegetables product: the effects of perceptions of quality and risk. International journal of scientific and technology research, 4(12), 28-36. Retrieved from http://www.ijstr.org/final-print/dec2015/Buying-Behavior-Of-Organic-Vegetables-Product-The-Effects-Of-P erceptions-Of-Quality-And-Risk-.pdf

Almossawi, M. M. (2012). Customer satisfaction in the mobile telecom industry in Bahrain: Antecedents and consequences. International Journal of Marketing Studies, 4(6), 139-156. Retrieved from https://doi.org/10.5539/ijms.v4n6p139

Ansari, A., \& Riasi, A. (2016). Modelling and evaluating customer loyalty using neural networks. Evidence from startup insurance companies. Future Business Journal, 2(1), 15-30. http://dx.doi.org/10.1016/j.fbj.2016.04.001

Arslan, Y., Gec sti, F., \& Zengin, H. (2013). Examining perceived risk and its influence on attitudes: A study on private label consumers in Turkey. Asia Social Science, 9(4), 158-166. Retrieved from https://doi.org/10.5539/ass.v9n4p158

Aydin, A., \& Ozer, G. (2005). The analysis of antecedents of customer loyalty in the Turkish mobile 
telecommunication market. European Journal of Marketing, 39(7/8), 910-925. http://dx.doi.org/10.1108/03090560510601833

Bayraktar, E., Tatoglu, E., Turkyilmaz, A., \& Zaim, S. (2012). Measuring the efficiency of customer satisfaction and loyalty for mobile phone brands with DEA. Expert Systems with Applications, 39, 99-106. http://dx.doi.org/10.1016/j.eswa.2011.06.041

Bagozzi, R. P., \& Yi, Y. (1988). On the Evaluation of Structural Equation Models. Journal of the Academy of Marketing Science, 16(1), 74-94. http://dx.doi.org/10.1007/BF02723327

Bagozzi, R. P., Li, Y., \& Philips, L. W. (1991). Assessing construct validity in organizational research. Administrative Science Quarterly, 36(3), 421-458. http://dx.doi.org/10.2307/2393203

Beisswanger, A. H., Stone, E. R., Hupp, J. M., \& Allgaier, L. (2003). Risk taking in relationships: Differences in deciding for oneself versus for a friend. Basic \& Applied Social Psychology, 25(2), 121-135. http://dx.doi.org/10.1207/S15324834BASP2502_3

Beneke, J., Greene, A., Lok, I., \& Mallett, K. (2012). The influence of perceived risk on purchase intent: the case of premium grocery private label brands in South Africa. Journal of Product \& Brand Management, 21(1), 4-14. http://dx.doi.org/10.1108/10610421211203060

Bollen, K. A. (1989). Structural Equations with Latent Variables, New York: Wiley. https://doi.org/10.1002/9781118619179

Byrne, B. M. (2010). Structural equation modeling with Amos: Basic concepts, applications, and programming (2nd ed.). New York, NY: Taylor and Francis Group.

Carmen, P. C. (2007). Perceived risk on goods and service purchases. EsicMarket, 129, 183-199. Retrieved from $\mathrm{http}: / /$ www.esic.edu/documentos/revistas/esicmk/080114_153323_I.pdf

Carmines, E. G., \& McIver, J. P. (1981). Analyzing Models with Unobserved Variables. In G.W. Bohrnstedt \& E. F. Borgatta (Eds.), Social Measurement: Current Issues, Beverly Hills, CA: Sage.

Clark, L. A., \& Watson, D. (1995). Constructing validity: Basic issues in objective scale development. Psychological Assessment, 7(3), 309-319. http://dx.doi.org/10.1037/1040-3590.7.3.309

Chaudhuri, A., \& Holbrook, M. B. (2001). The chain of effects from brand trust and brand affect to brand performance: the role of brand loyalty. Journal of Marketing, 65(2), 81-93. Retrieved from https://doi.org/10.1509/jmkg.65.2.81.18255

Cheng, S. I. (2011). Comparisons of competing models between attitudinal loyalty and behavioral loyalty. International Journal of Business and Social Science, 2(10), 149-166. Retrieved from http://ijbssnet.com/journals/Vol._2_No._14;_July_2011/18.pdf

Cox, D. F., \& Rich, S. U. (1964). Perceived risk and consumer decision making-the case of telephone shopping. Journal of Market Research, 1(4), 32-39. http://dx.doi.org/10.2307/3150375

Eshghi, A., Roy, S. K., \& Ganguli, S. (2008). Service quality and customer satisfaction: An empirical investigation in Indian Mobile telecommunications services. Marketing Management Journal, 18(2), 119-114. Retrieved from http://www.mmaglobal.org/publications/MMJ/MMJ-Issues/2008-Fall/MMJ-2008-Fall-Vol18-Issue2-Eshghi -Roy-Ganguli-pp119-144.pdf

Fornell, C., \& Larcker, D. F. (1981). Evaluating structural equation models with unobservable variables and measurement error. Journal of Marketing Research, 18(1), 39-50. http://dx.doi.org/10.2307/3151312

Fornell, C. (1992). A national customer satisfaction barometer: The Swedish experience. Journal of Marketing, 56, 6-21. http://dx.doi.org/10.2307/1252129

Hair, J. F., Anderson, R. E., Tatham, R. L., \& Black, W. C. (1998). Multivariate Data Analysis. Prentice Hall, New Jersey

Hafeez, S., \& Hasnu, S. (2010). Customer satisfaction for Cellular phones in Pakistant: A case study of Mobilink. Business and Economics Research Journal, 1(3), 35-44. Retrieved from http://www.berjournal.com/customer-satisfaction-for-cellular-phones-in-pakistan-a-case-study-of-mobilink

Hassan, M., Hassan, S., Nawaz, M. S., \& Aksel, I. (2013). Measurement customer satisfaction and loyalty through service fairness, service quality and price fairness perception: an empirical study of Pakistan Mobile telecommunication sector. Aci.Int (Lahore), 25(4), 971-980. Retrieved from 
http://www.sci-int.com/pdf/204359195453--971-980--masood\%20\&\%20Saad\%20final.pdf

Hellier, P. K., Geursen, G. M., Carr, R. A., \& Rickard, J. A. (2003). Customer repurchase intention: A general structural equation model. European Journal of Marketing, 37(11/12), 1762-1800. https://doi.org/10.1108/03090560310495456

Hu, L. T., \& Bentler, P. M. (1999). Cutoff Criteria for Fit Indexes in Covariance Structure Analysis: Conventional Criteria versus New Alternatives. Structural Equation Modeling, 6(1), 1-55. http://dx.doi.org/10.1080/10705519909540118

Hume, M., Mort, G. S., \& Winzar, H. (2007). Exploring repurchase intention in a performing arts context: Who comes? And why do they come back? International Journal of Nonprofit and Voluntary Sector Marketing, 12(2), 135-148. http://dx.doi.org/10.1002/nvsm.284

Hooper, D., Coughlan, J., \& Mullen, M. R., (2008). Structural Equation Modelling: Guidelines for Determining Model Fit. The Electronic Journal of Business Research Methods, 6(1), 53-60. Retrieved from http://arrow.dit.ie/cgi/viewcontent.cgi?article=1001\&context=buschmanart

Hox, J. J. (2002). An introduction to Structural Equation Modeling. Family Science Review, 11, 354-373. Retrieved from http://joophox.net/publist/semfamre.pdf

Ishaqa, M. I. (2012). Perceived value, Service quality, corporate image and customer loyalty: Emperical assessment from Pakistan. Serbian Journal of Management, 7(1), 25-36. Retrieved from https://doi.org/10.5937/sjm1201025I

Jacoby, J., \& Kaplan, L. B. (1972). The Components of Perceived Risk. Paper presented at the Third Annual Convention of the Association for Consumer Research, 382-393. Retrieved from http://www.acrwebsite.org/search/view-conference-proceedings.aspx?Id=12016

Jallow, M. (2013). Customer Satisfaction in Taipei Mobile Phone Sector. African Journal of Business Management, 7(6), 272-380. http://dx.doi.org/10.5897/AJBM10.623

Joreskog, K. G., \& Sorbom, D., (1993). LISREL 8: Structural equation modeling with the SIMPLIS command language. Chicago: Scientific Software International.

Jones, T. O., \& Sasser W. E. (1995). Why Satisfied Customers Defect. Harvard Business Review, (Nov-Dec), 88-99. http://dx.doi.org/10.1061/(ASCE)0742-597X(1996)12:6(11.2)

Jones, T., \& Taylor, S. F. (2007). The conceptual domain of service loyalty: how many dimensions? Journal of Services Marketing, 21(1), 36-51. http://dx.doi.org/10.1108/08876040710726284

Kline, R. B. (2005), Principles and Practice of Structural Equation Modeling ( $2^{\text {nd }}$ ed.). New York: The Guilford Press.

Khan, S. A, Ramzan, N., Shoaib, M., \& Mohyuddin, A. (2015). Impact of Word of Mouth on consumer purchase intention. Sci.Int. (Lahore), 27(1), 479-482. Retrieved from http://www.sci-int.com/pdf/1812633232479-482--Saba\%20Anwar\%20Khan--SS--CO-ZEESHAN--.pdf

Khalid, S., Ahmed, M. A., \& Ahmad, Z. (2013). Word - of Mouth communications: A powerful contributor to Consumers Decision - making in Healthcare Market. International Journal of Business and Management Invention, 2(5), 55-64. Retrieved from http://www.ijbmi.org/papers/Vol(2)5/version-2/I255564.pdf

Kim, M. K., Park, M. C., \& Jeong, D. H. (2004). The effects of customer satisfaction and switching barrier on customer loyalty in Korean mobile telecommunication services. Telecommunications policy, 28, 145-159. http://dx.doi.org/10.1016/j.telpol.2003.12.003

Lampert, S. I., \& Rosenberg, L. J. (1975). Word of mouth activity as information search: A reappraisal. Journal of the Academy of Marketing Science, 3(4), 337-354. http://dx.doi.org/10.1007/BF02729294

Lee, R., \& Murphy, J. (2008). The moderating influence of enjoyment on customer loyalty. Australasian Marketing Journal, 16(2), pp. 11-21. http://dx.doi.org/10.1016/S1441-3582(08)70011-9

Lee, J., Lee, J., \& Feick, L. (2001). The impact of switching cost on the customer satisfaction-loyalty link; mobile phone service in France. Journal of Service Marketing, 15(1), 35-48. http://dx.doi.org/10.1108/08876040110381463

Lin, T. M. Y., \& Fang, C. H. (2006). The effects of perceived risk on the word-of-mouth communication dyad. Social behavior and personality, 34(10), 1207-1216. http://dx.doi.org/10.2224/sbp.2006.34.10.1207

Liu, C. T., Guo, Y. M., \& Lee, C. H. (2011). The effects of relationship quality and switching barriers on 
customer loyalty. International Journal of Information management, 31, 71-79. http://dx.doi.org/10.1016/j.ijinfomgt.2010.05.008

MacCallum, R. C., Browne, M. W., \& Sugawara, H. M. (1996). Power Analysis and Determination of Sample Size for Covariance Structure Modeling. Psychological Methods, 1(2), 130-149. Retrieved from http://ww.w.statpower.net/Content/312/Handout/MacCallumBrowneSugawara96.pdf

Mason, R. (2008). Word of mouth as a promotional tool for turbulent markets. Journal of Marketing Communications, 14(3), 207-224. http://dx.doi.org/10.1080/13527260701754258

Malhotra, N. K. (2004). Marketing Research: An Applied Orientation (4th Ed.). Pearson Education, Inc., New Jersey.

Maisam, S., \& Mahsa, R. D. (2016). Positive Word-of -Mouth Marketing: Explaining the role of value congruity and brand love. Journal of Competitiveness, 8(1), 19-27. http://dx.doi.org/10.7441/joc.2016.01.02

McQuitty, S. (2004). Statistical power and structural equation models in business research. Journal of Business Research, 57(2), 175-183. http://dx.doi.org/10.1016/S0148-2963(01)00301-0

Ministry of Information \& Communications. (2016). Vietnam had signed up over 128.3 million mobile subscribers. Retrieved from http://ictnews.vn/vien-thong/viet-nam-hien-co-hon-128-3-trieu-thue-bao-dien-thoai-di-dong-142931.ict

Mitchell, V. W. (1999). Consumer perceived risk: conceptualisations and models. European Journal of Marketing, 33(1/2), 163-195. http://dx.doi.org/10.1108/03090569910249229

Nasir, A., \& Mushtaq. (2014). Customer loyalty in telecom sector of Pakistan. Journal of Sociological Research, 5(1), 449-467. http://dx.doi.org/10.5296/ jsr.v5i1.6575

Nunnally, J. C. (1967). Psychometric theory. New York: McGraw-Hill.

Oliver, R. L. (1999). Whence customer loyalty? Journal of Marketing, 63, 33-44. http://dx.doi.org/10.2307/1252099

Samad, A. (2014). Examining the impact of perceived service quality demensions on repurchase intentions and word of mouth. Journal of Business and Management, 16(1), Ver. III, 37-41. Retrieved from http://iosrjournals.org/iosr-jbm/papers/Vol16-issue1/Version-3/E016133741.pdf

Schiffman, G. L., \& Kanuk, L. L. (2010). Consumer behavior (10 ${ }^{\text {th }}$ Ed.). New Jersey: Prentice Hall.

Schumacker, R. E., \& Lomax, R. G. (2004). A Beginner's Guide to Structural Equation Modeling (2nd Ed). Mahwah, NJ: Lawrence Erlbaum Associates.

Steiger, J. H. (1990). Structural model evaluation and modification: an interval estimation approach. Multivariate Behavioural Research, 25, 173-180. http://dx.doi.org/10.1207/s15327906mbr2502_4

Steiger, J. H. (2007). Understanding the limitations of global fit assessment in structural equation modeling. Personality and Individual Differences, 42(5), 893-898. http://dx.doi.org/10.1016/j.paid.2006.09.017

Straub, D. W. (1989). Validating instruments in MIS research. MIS Quarterly, 13(2), 147-169. http://dx.doi.org/10.2307/248922

Söderlund, M. (2006). Measuring customer loyalty with multi - item scales: A case for caution. International Journal of Service Industry Management, 17(1), 76-98. http://dx.doi.org/10.1108/09564230610651598

Tabachnick, B. G., \& Fidell, L. S. (1996). Using Multivariate Statistics. Harper Collins, New York.

Taylor, J. W. (1974). The role of risk in consumer behavior. Journal of Marketing, 38(2), 53-60. http://dx.doi.org/10.2307/1250198

Tuu, H. H, Olsen, S. O., \& Linh, P. T. T. (2011). The moderator effects of perceived risk, objective knowledge and certainty in the satisfaction- loyalty relationship. Journal of Consumer Marketing, 28(5), 363-375 http://dx.doi.org/10.1108/07363761111150017

Tho, N. X., \& Tuu, H. H. (2012). The effect of destination image and perceived risk on intention of returning and positive WOM: A case study about visitors who visited the beach of Cua Lo, Vietnam. Economics and Administration Review, 4(September), 54-59. Retrieved from http://www.ntu.edu.vn/Portals/62/Bai\%20bao\%20nam\%202012/Huy\%20Tuu\%20\&\%20Xuan\%20Tho.pdf [Vietnamese]

Vranakis, S., Chatzoglou, P., \& Mpaloukas, A. (2012). Customer satisfaction of Greek Mobile phone services. 
International Journal of Managing Value and Supply Chains (IJMVSC), 3(4), 43-54. Retrieved from https://doi.org/10.5121/ijmvsc.2012.3404

Yanamandram, V., \& White, L. (2006). Exploratory and confirmatory factor analysis of the perceived switching costs model in the business services sector, Australia and New Zealand Marketing Academy Conference, Brisbane, Queensland, 4-6 December 2006. Retrieved from http://ro.uow.edu.au/cgi/viewcontent.cgi?article=1240\&context=commpapers

Zhang, L., Tan, W., Xu, Y., \& Tan, G. (2012). Demension of consumers' perceived risk and their influences on online consumer's purchase behavior. Communications in information science and management engineering (CISME), 2(7), 8-14. Retrieved from http://CISME10270-20120725-102911-1342-595\%20(2).pdf

\section{Copyrights}

Copyright for this article is retained by the author(s), with first publication rights granted to the journal.

This is an open-access article distributed under the terms and conditions of the Creative Commons Attribution license (http://creativecommons.org/licenses/by/4.0/). 